\title{
Redescription of Oswaldocruzia chambrieri (Strongylida: Molineidae) from Rhinella margaritifera (Anura: Bufonidae) in Caxiuanã National Forest, Brazil
}

\author{
Yuri Willkens ${ }^{1}$, Arnaldo Maldonado Jr. ${ }^{2}$, Jeannie Nascimento dos Santos ${ }^{1}$, \\ Gleomar Fabiano Maschio ${ }^{3}$ and Francisco Tiago de Vasconcelos Melo ${ }^{1 *}$ \\ ${ }^{1}$ Laboratório de Biologia Celular e Helmintologia "Profa. Dra. Reinalda Marisa Lanfredi" - Instituto de Ciências Biológicas, \\ Universidade Federal do Pará, Brazil; ${ }^{2}$ Laboratório de Biologia e Parasitologia de Mamíferos Silvestres Reservatórios, \\ Instituto Oswaldo Cruz - Pavilhão Arthur Neiva, Brazil; ${ }^{3}$ Laboratório Multidisciplinar da Biologia a Distância, \\ Instituto de Ciências Biológicas, Universidade Federal do Pará, Brazil
}

\begin{abstract}
Oswaldocruzia chambrieri Ben Slimane et Durette-Desset, 1993 is redescribed from specimens collected from the small intestine of the South American common toad, Rhinella margaritifera, from Caxiuanã National Forest in Pará, Brazil, using light and scanning microscopy and molecular analysis of Cytochrome Oxidase I (COI) - coding regions of DNA. The discovered nematodes are characterized by a type III caudal bursa with two papillae, rays 4 with a median groove, and spicules divided into a blade, a shoe and a fork. Cervical alae are absent, the cephalic vesicle is divided into two portions, and the synlophe has low ridges without chitinous supports. The present study establishes the Caxiuanã National Forest as a new location for $O$. chambrieri, which had previously been reported as a parasite of $R$. margaritifera in Ecuador, uses light microscopy and scanning electron microscopy (SEM) to identify new morphological characters of the species and represents the second molecular sequence deposited for the Oswaldocruzia genus.
\end{abstract}

\section{Keywords}

Nematodes, Trichostrongyloidea, new morphological data, Brazilian Amazon

\section{Introduction}

Rhinella margaritifera (Laurenti, 1768) is a complex group represented by 16 formally recognized species, 13 of which occur in the Amazon basin. These species are represented by members of several communities of Neotropical medium-sized toads that inhabit the litter of humid tropical forests (Lavilla et al. 2013; Moravec, et al. 2014).

Distributed across the Neotropical region, from the southern United States to southern South America (Frost, 2014), these species have particularly been found in the northern part of South America (Venezuela, Colombia, Ecuador, Bolivia, Peru, Brazil, Suriname, Guyana and French Guiana) and in Central America (Panamá). The cryptic coloration of these toads resembles the pattern of fallen leaves and partially decomposed matter in the soil, producing a camouflage effect that is enhanced by body contours, the presence of cranial el- evations on the crests, and the neural crests of certain species' vertebrae (Dos Santos et al. 2015; Lavilla et al. 2013).

The genus Oswaldocruzia Travassos, 1917 has a worldwide distribution and includes approximately 88 species (Svitin and Kuzmin, 2012). Currently, 41 species are known to exist in the Neotropical region, 14 of which have been reported from South American amphibians; only eight of these species have been described as parasites of amphibians and reptiles in Brazil (Guerrero, 2013; Campião et al. 2014).

During studies on the genus Oswaldocruzia, we examined specimens collected from $R$. margaritifera from Caxiuanã National Forest in Pará, Brazil. Based on our analyses, we assigned these specimens to Oswaldocruzia chambrieri Ben Slimane et Durette-Desset, 1993. Morphological examinations using light microscopy and scanning electron microscopy (SEM) allowed us to not only assess particular morphological 
characters of the genus and assign the specimens to $O$. chambrieri but also add new information to the species description and molecular data.

\section{Material and Methods}

Eleven specimens of $R$. margaritifera were collected from Caxiuanã National Forest, Pará, Brazil, during March 6-12, 2014. The toads were anesthetized with ketamine, weighed and necropsied in a laboratory at Ferreira Penna Scientific Station. All intestinal nematodes were collected and fixed in a heated $70 \%$ alcohol solution. Certain specimens were transferred to $100 \%$ ethanol and stored in a freezer at $-20^{\circ} \mathrm{C}$ for molecular examinations. Data regarding the host, the number of helminths found and helminth locations were also registered.

After fixation, certain nematodes were clarified in lactophenol and mounted on temporary slides for morphological and morphometrical analysis with an Olympus BX 41 microscope (Olympus, Tokyo, Japan) equipped with a drawing tube. All of the specimens were stored in glycerin alcohol and deposited in the invertebrate collection of the Emílio Goeldi Paraense Museum in Belém. Measurements are given in micrometers unless otherwise as indicated. All measurements are presented as mean values followed by ranges in parentheses. For scanning electron microscopy, specimens were post-fixed in $1 \% \mathrm{O}_{2} \mathrm{Os}_{4}$, dehydrated in an ascending ethanol series and dried at the critical point of $\mathrm{CO}_{2}$. Nematodes were mounted on metalic stubs, coated with gold and examined using a Vega3 (TESCAN) microscope from Laboratory of Embryology and Histology (Laboratório de Embriologia e Histologia - LHEA/UFRA).

For molecular analysis, nematodes were subjected to DNA extraction using a QIAamp DNA Mini 51304(50) Qiagen ${ }^{\circledR}$ kit. Polymerase chain reaction (PCR) was performed to amplify Cytochrome Oxidase I (COI)-coding regions of DNA, using methods and primers described by Prosser et al. (2013). Amplified fragments were directly sequenced in accordance with the manufacturer's protocol for the ABI PRISM Dye Terminator Cycle Sequencing Ready Reaction kit (Perkin-Elmer Cetus, Noortwalk, CA, USA). The reaction products were sequenced using an ABI PRISM ${ }^{\mathrm{TM}} 310$ Genetic Analyzer. The obtained sequences were aligned using ClustalW software (Thompson et al. 1994) and were compared with sequences that had previously been deposited in GenBank (http://www. ncbi.nlm.nih.gov/genbank/). Molecular biology analysis were conducted in the Laboratory of Biology and Parasitology of Wild Reservoir Mammals at Foundation Institute Oswaldo Cruz, Rio de Janeiro, Brazil.

\section{Results}

Among the 11 analyzed specimens of $R$. margaritifera, 9 were infected with $O$. chambrieri (a prevalence of $81 \%$ ); in total,
264 specimens were collected, with range of infection 15 to 50 , a mean intensity of 29.3 and a mean abundance of 24 .

Molecular analysis of 697 base pairs of COI gene $\left(\mathrm{Os}_{\mathrm{s}}\right.$ waldocruzia chambrieri from present study, GenBank accession number KU980934) identified $92 \%$ similarity of the studied sequence to that from an Oswaldocruzia sp., a parasite of Trachycephalus venulosus that has already been deposited in GenBank.

\section{Order Strongylida Molin, 1861}

\section{Superfamily Trichostrongyloidea Cram, 1927 Family Molineidae Durette-Desset et Chabaud, 1977 Oswaldocruzia chambrieri Ben Slimane et Durette-Desset, 1993}

Host: Rhinella margaritifera (Laurenti, 1768)

Infection site: Small intestines

New locality: Caxiuanã National Forest $\left(1^{\circ} 47^{\prime} 32.3^{\prime \prime} S\right.$, $\left.51^{\circ} 26^{\prime} 02.5^{\prime \prime} \mathrm{W}\right)$, Pará, Brazil

Prevalence: $81 \%$

Intensity of infection: 29.3

Voucher specimens: MPEG. NEM 66, MPEG. NEM 67.

General description: Small and thin nematodes, cephalic vesicle smooth, divided into two parts, a wider anterior portion and one narrower posterior portion (Fig. 3A). Transverse cuticle striations and longitudinal ridges present, appearing immediately after cephalic dilation, emerging irregularly, some appearing, some disappearing along body (Fig. 3A, 3C, 3E, 3F, $3 \mathrm{G})$. Esophagus claviform, nerve ring just anterior to its midlength (Fig. 1A, 2A), excretory pore (Fig. 3E) interrupting the ridges just anterior to deirids (Fig. 1A, 2A, 3E). Oral opening triangular, 6 externo-labial papillae, 4 cephalic papillae and 2 amphids (Fig. 3B). Female with vulva at posterior half of body, well-developed amfidelphic ovojector (Fig. 2D, 3F). Tail conical, cuticular spine present (Fig. 2E, 3G, 3H). Males with caudal bursa supported by rays following the distribution pattern 2-1-2 (Fig. 4A, 4B). Spicules equal, surrounded by hyaline membrane and divided into three parts (Fig. 1F, 1G).

Male (based on 9 specimens). Length $5.46 \pm 0.58$ (4-6) $\mathrm{mm}$. Approximately 27 longitudinal crests at esophagus level and 41 at mid body level (Fig. 1B, 1C). Cephalic vesicle length $68.89 \pm 6.64$ (61-83). Nerve ring $160.56 \pm 12.63(140$ $181)$, excretory pore $286.56 \pm 21.98(239-312)$ and deirids at $304.89 \pm 20.86(261-336)$ from apex. Esophagus length $429.89 \pm 29.26(396-445)$. Excretory pore-esophagus ratio $0.67 \pm 0.07(0.57-0.79)$. Width at midbody $121.67 \pm 25.35$ (80-147). Caudal bursa trilobed with a pair of internal papillae between rays 3 and 4. Bursa of type III (see Ben Slimane et al. 1996), rays 2 and 3 running parallel throughout, reaching edge of bursal membrane; rays 4,5 , and 6 with common origin, ray 4 short, with a medial groove, not reaching bursal margin, presenting an external dorsal papilla, separated from 5 and 6 . Rays 5 and 6 running throughout, turning caudate and reaching edge of bursal membrane. Rays 6 and 8 with inde- 

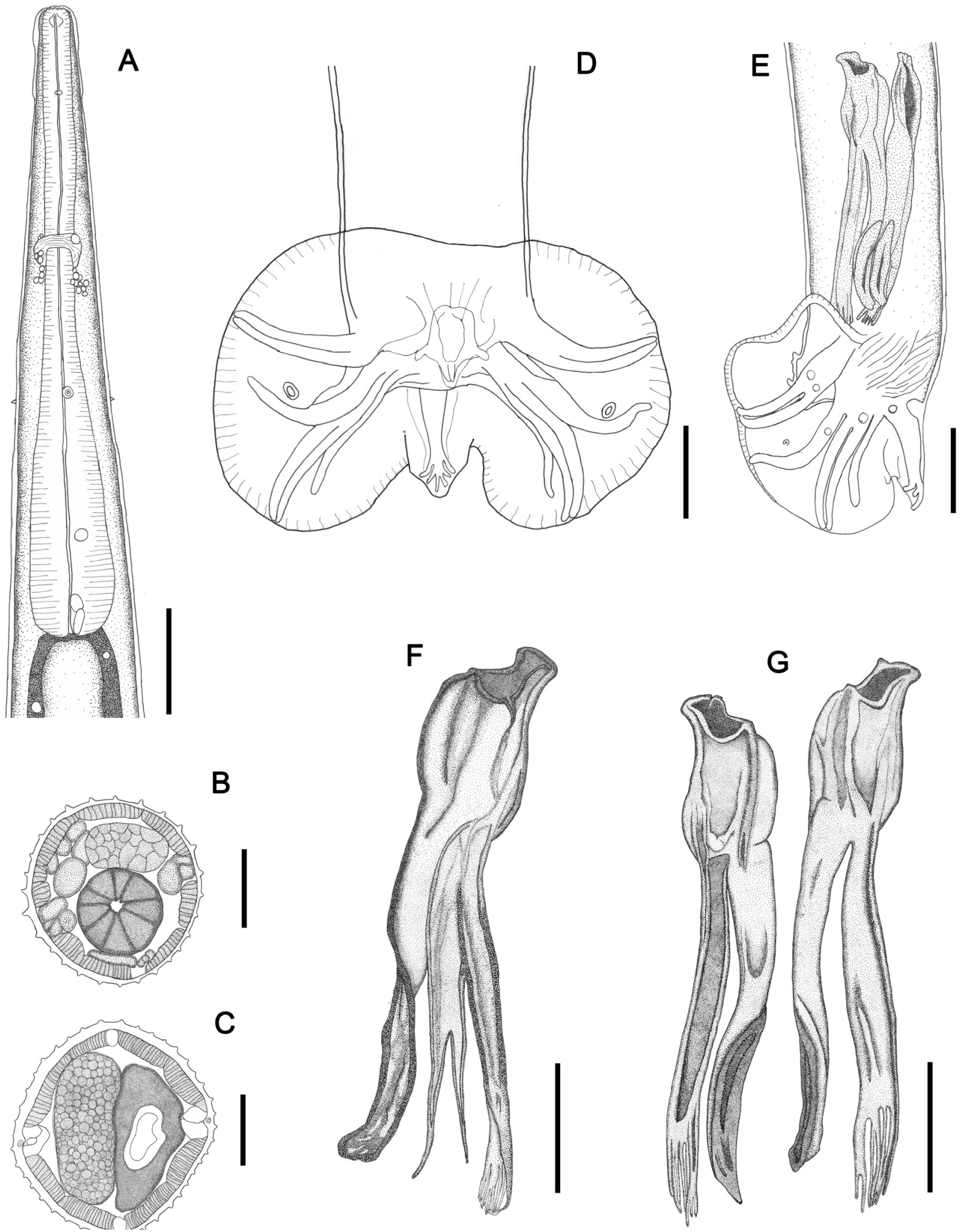

Fig. 1. Line drawings of Oswaldocruzia chambrieri males from Rhinella margaritifera. A - Anterior end, ventral view; B - Transverse section at esophagus level; $\mathbf{C}$ - Synlophe in transverse section at mid-body; D - Ventral view of caudal bursa; $\mathbf{E}-$ Lateral view of caudal bursa; $\mathbf{F}$ - Lateral view of the spicule; $\mathbf{G}-$ Dorsal view of the spicule. Scale bars: $A=75 \mu \mathrm{m} ; \mathrm{B}=30 \mu \mathrm{m}, \mathrm{C}, \mathrm{F}, \mathrm{G}=40 \mu \mathrm{m} ; \mathrm{D}=25 \mu \mathrm{m} ; \mathrm{E}=50 \mu \mathrm{m}$ 

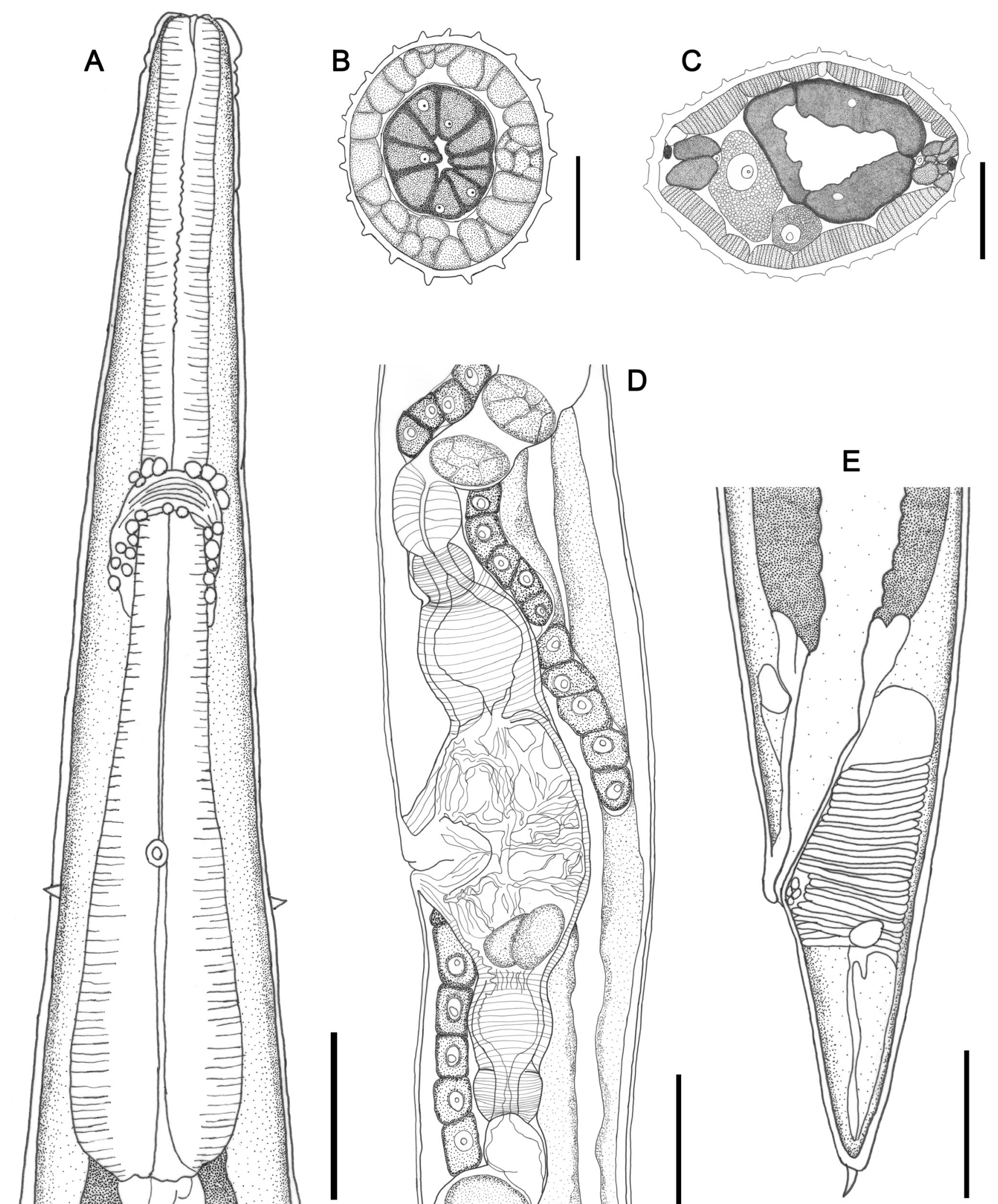

Fig. 2. Line drawings of Oswaldocruzia chambrieri females from Rhinella margaritifera. A - Anterior end, ventral view; B - Transverse section at esophagus level; $\mathbf{C}$ - Synlophe in transverse section at mid-body; $\mathbf{D}$ - Lateral view of vulva and ovojector; $\mathbf{E}$ - Lateral view of tail, with cuticular spine. Scale bars: $A, D=50 \mu \mathrm{m} ; \mathrm{B}=30 \mu \mathrm{m}, \mathrm{C}=40 \mu \mathrm{m} ; \mathrm{D}=100 \mu \mathrm{m}$ 

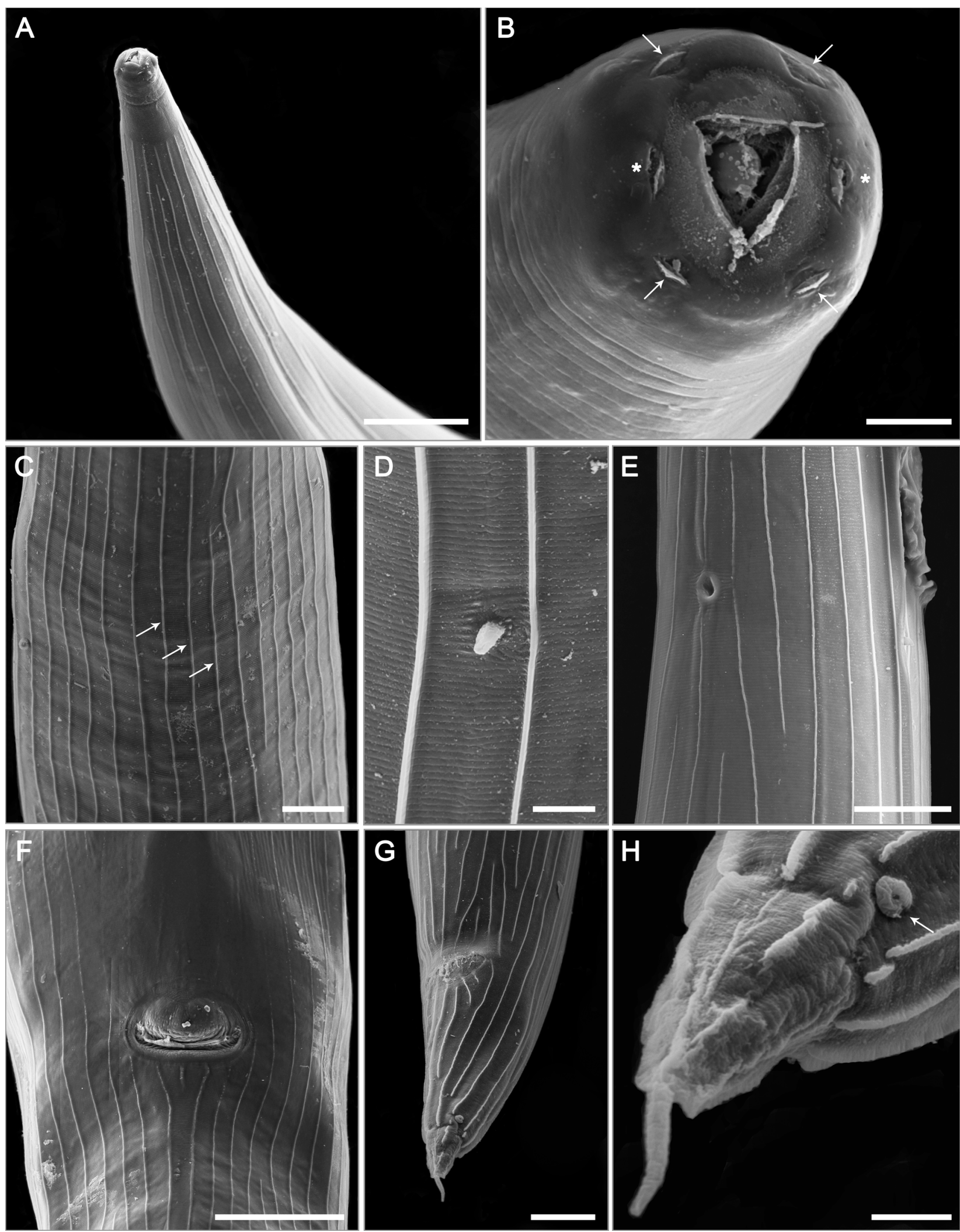
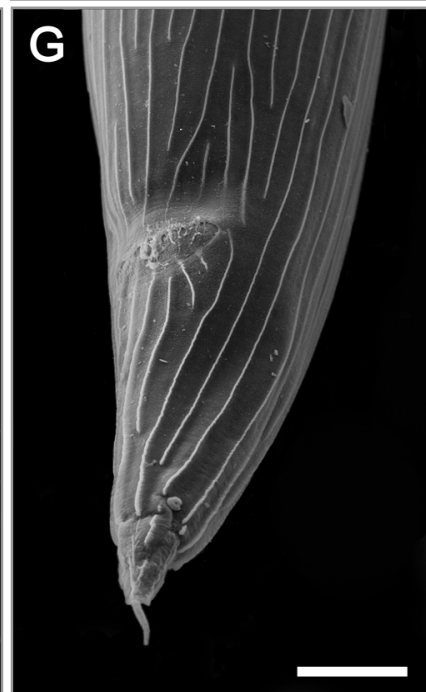

$\mathrm{H}$

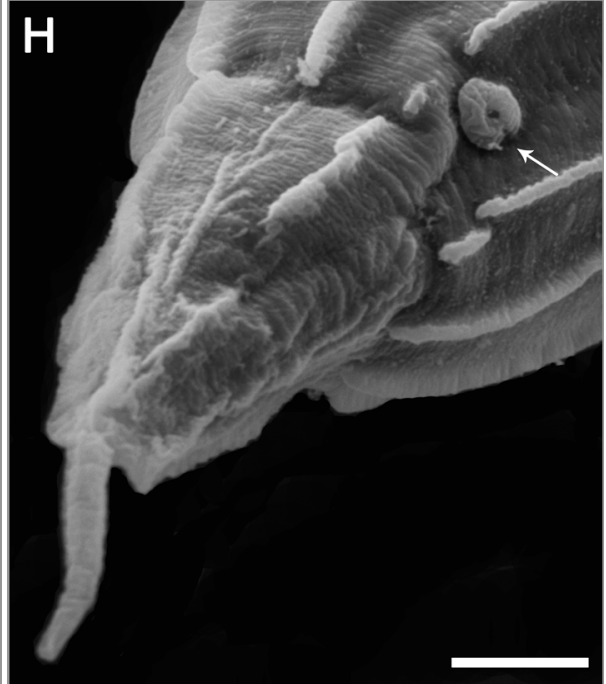

Fig. 3. Oswaldocruzia chambrieri, scanning electron photomicrographs. A-Anterior region and cephalic structures; B - Apical view of the anterior end, mouth opening with esophageal teeth, 4 cephalic papillae (arrow) and 2 amphids; C - Details of longitudinal ridges; D - Deirid; $\mathbf{E}$ - Excretory pore; $\mathbf{F}$ - Posterior third of female body showing the vulva and the distribution of the ridges, $\mathbf{G}-$ Female posterior end showing anus and pattern of the ridges; $\mathbf{H}-$ Details of tail, showing the phasmid (arrow) and the cuticular spine. Scale bars: A, F = 50 $\mu$ m; B, D, $\mathrm{H}=5 \mu \mathrm{m} ; \mathrm{C}, \mathrm{E}, \mathrm{G}=20 \mu \mathrm{m} ; \mathrm{D}, \mathrm{E}$ 

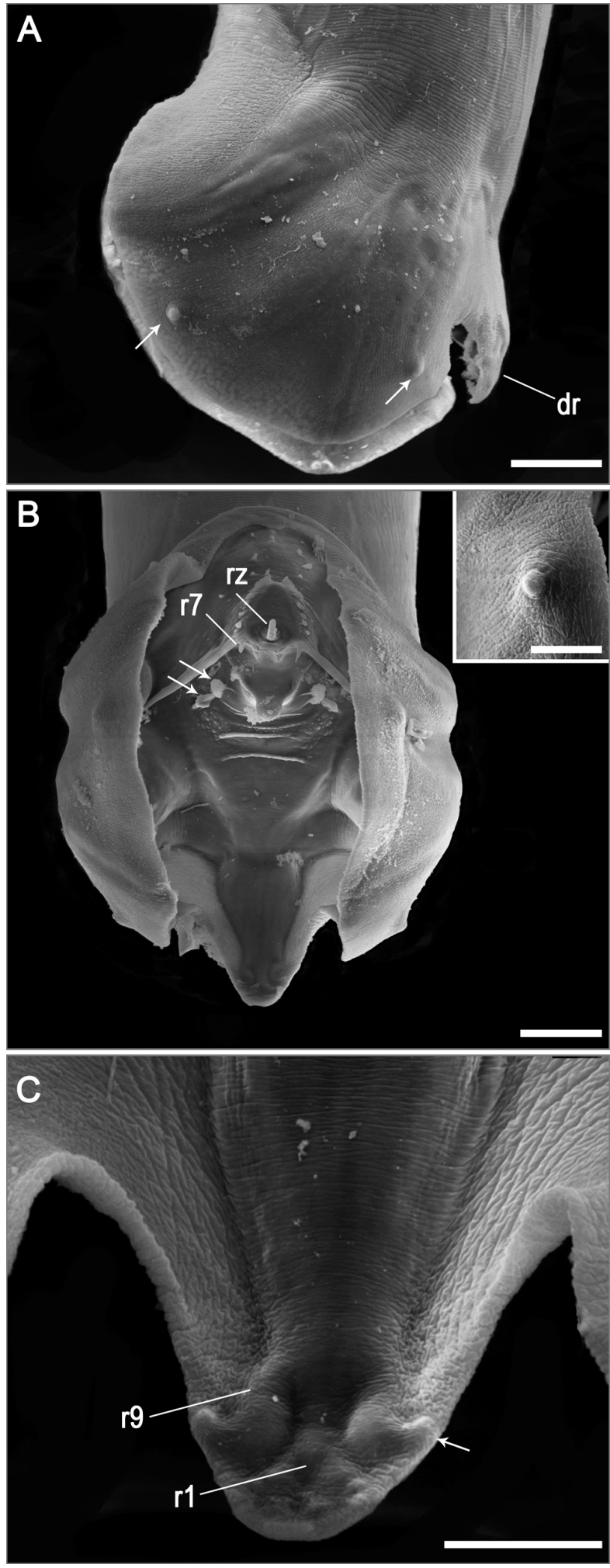

Fig. 4. Oswaldocruzia chambrieri, scanning electron photomicrographs. A-Lateral view of posterior region of male, showing rays 2 6 and 8 supporting caudal bursa, two bursal papillae (arrows) and dorsal ray (dr). B - Ventral view of caudal bursa evidencing genital cone, rays 7 (r7), and zero (rz) and two papillae (arrows). Inset. Details of bursal papillae $\mathbf{C}$ - Details of the dorsal lobe with rays9 (r9) with papilla (arrow) and ray 10 (r10). Scale-bars: $A, B=20 \mu \mathrm{m}, \mathrm{C}=10 \mu \mathrm{m}$ pendent origin. Origin of ray 8 running parallel to ray 6 , except distally and not reaching bursal margin, but ending in a dorsal papilla in bursa (Fig. 1D, 4A). Dorsal ray ending with a small pair of papillae (Fig. 4C). Genital cone well developed; ray zero present at anterior margin, with a small anterior projection and flanked by rays 7 . Two pairs of ventral bursal papilla anterior to genital cone (Fig. 4B). Right spicule 181.56 \pm 8.59 (174-193) and left spicule $181.22 \pm 8.76$ (171-192) long, both divided proximally in 3 branches: shoe spoon-like, blade divided distally in 6 processes and fork divided in posterior third occupying about $23 \%$ of spicule length.

Female (based on 9 specimens). Length $7.97 \pm 1.29$ (6.9311) $\mathrm{mm}$. Approximately 21 longitudinal crests at esophagus level and 33 at mid body level (Fig. 2B, 2C). Cephalic vesicle length $65.11 \pm 5.42(61-72)$. Nerve ring $168.89 \pm 10.08(152-$ $184)$, excretory pore $291 \pm 29.92(256-344)$ and deirids at $312.44 \pm 35.91$ (277-371) from apex respectively. Esophagus length $479 \pm 19.81$ (440-504). Excretory pore-esophagus ratio $0.61 \pm 0.06(0.53-0.71)$. Width at midbody $168.89 \pm 17.55$ (147-187). Vulva, with dorsal lip prominent, with transverse semilunar shape, at $2.34 \pm 0.22(2.7-2.04) \mathrm{mm}$ from de apex. Vagina vera length $109.56 \pm 16.75$ (139-93). Ovojector divided in vestibule $379.22 \pm 39.48$ (326.66-389.33) length, anterior and posterior sphincters $40.78 \pm 9.55$ (21-53) and 35.11 \pm 8.96 (24-56) length; and anterior and posterior infundibula $40.44 \pm 6.86$ (34-53) and $43.22 \pm 6.72$ (34-53) length respectively (Fig. 2D). Tail length $121.22 \pm 9.73$ (105-138) and width at anus level $67.11 \pm 11.46$ (58-93) ending with cuticular spine $15.44 \pm 4.59$ (12-24), phasmids, circular, with prominent border (Fig. 2E, 3G, 3H). Eggs in morula stage $41.78 \pm 2.28(38-44) \times 71.22 \pm 2.33(67-74)$.

\section{Discussion}

The nematodes described here possess a club-shaped esophagus, a cephalic vesicle divided into two portions, a cuticle with fine transverse striations and longitudinal low ridges along the body without chitinous support that constitute the synlophe. Males are devoid of gubernaculum and have robust spicules divided into three parts that are surrounded by a hyaline membrane. The caudal bursa is supported by rays in a 2-1-2 pattern and has triangular dorsal lobe. Females have an amphidelphic uterus, a vulva located in the posterior half of the body, and a tapered tail ending with a cuticle spine. Based on the findings of Vicente et al. (1991) and Anderson et al. (2009), these morphological features allowed us to assign the species to the genus Oswaldocruzia.

Oswaldocruzia species are divided into five groups that are characterized by spicule morphology and distribution region. Morphologically, the species within each group are extremely similar. However, the morphologies of the caudal bursa and the male spicules are the important morphological characters that contribute to specific diagnoses of these helminths (Ben Slimane et al. 1996). 


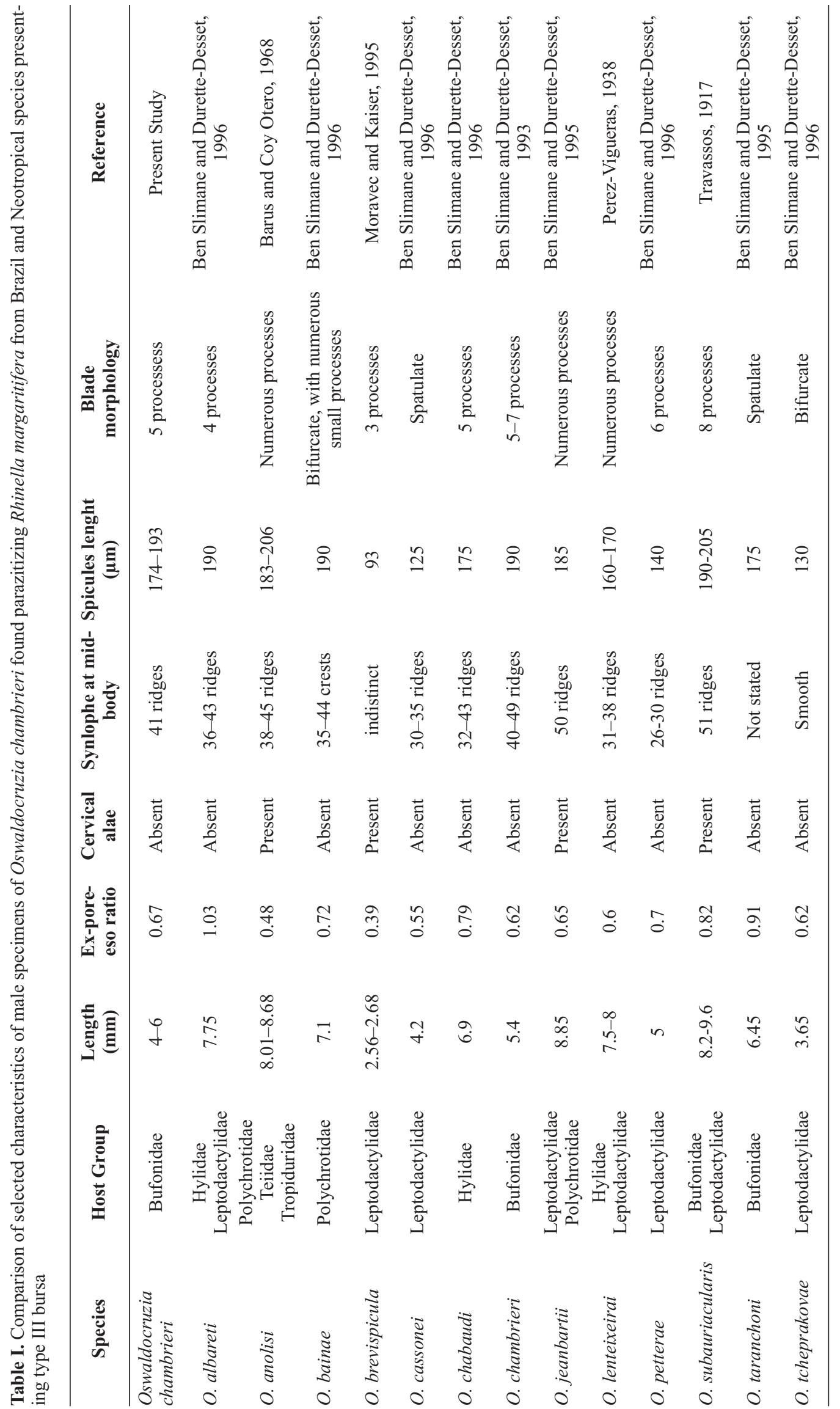


Among the 41 Neotropical species of the genus, the $O s$ waldocruzia found in the present study has a type III caudal bursa. Among the 13 congeners with a type III bursa, this nematode differs from $O$. anolisi, $O$. brevispicula, $O$. jeanbarti and $O$. subauricularis due to the absence of cervical alae; from O. bainae, O. cassonei, O. chabaudi, O. taranchoni and $O$. tcheprakovae due to the length and morphology of the spicules; and from $O$. albareti and $O$. petterae due to the number of ridges at the midbody, total body length and the excretory pore-esophagus ratio. This species is closely related to $O$. chambrieri with respect to morphologic characters and morphometry (Table I).

In the present study, using light microscopy, we also observed that the analyzed specimens have a pair of internal bursal papillae and that ray 4 has a medial groove. The presence of a medial groove in ray 4 has also been observed in another Molineidae nematode species by Feitosa et al. (2015). This character could be present in all species of the family and should be added to diagnostic traits for the family; however, detailed studies of these species are necessary.

SEM revealed ultrastructural features of the nematodes, allowing us to observe taxonomically relevant details for the genus that cannot be seen using light microscopy (Feitosa et al. 2015; Santos et al. 2008). In the present study, we utilized SEM analysis to confirm the structure of the oral opening and the papilla distribution as well as the shape of the excretory pore, the deirids and the longitudinal cuticular ridges along the body. In addition, we confirmed the disposition of the bursal rays and the presence of dorsal bursal papillae.

The examined species is the third Oswaldocruzia species observed using SEM. Santos et al. (2008) described ultrastructural features of various structures, such as cuticular ridges, cephalic structures, deirids, the rays and papillae of the caudal bursa (which were characterized in detail), the genital cone of males, and the corresponding rays, as potentially representative of the genus; these researchers also indicated the discontinuous nature of the longitudinal ridges along the body, which resulted in varying numbers of ridges. Feitosa et al. (2015) also observed this variation in a species of nematode from a different genus in the Molineidae family; thus, we emphasize that this feature is not consistently observed among Oswaldocruzia species alone and must therefore be carefully analyzed before being included as a taxonomic character

The results of molecular analysis suggest that the relationship between $O$. chambrieri of the present study and Oswaldocruzia sp. parasite of Trachycephalus venulosus might be hardly established because of the absence of molecular information on other species from Neotropics and from related hosts, as well as on the morphology of Oswaldocruzia sp.

Thus, the present study represents the first report of O. chambrieri in Brazil, the third Oswaldocruzia species observed by SEM, the second sequence deposited for this genus and the first such sequence for which the species has been identified.
Acknowledgements. We are grateful to Dra. Elane Guerreiro Giese from the Laboratory of Animal Embriology and Histology from the Universidade Federal da Amazônia, Belém for their technical support with the SEM analyses. Financial support for this study was provided by the PROPESP/PPGBAIP/UFPA, CAPES Foundation, the Ministry of Education of Brazil (grant CAPES-PARASITOLOGIA BÁSICA/2010), and the National Council for Scientific and Technological Development (CNPq) (grants SISBiota 2010-Sistema Nacional de Pesquisa em Biodiversidade, PVE CAPES/CNPq A 033/2013; CNPq Research grant productivity of JNS; scientific initiation research fellowship to YWOC). This study is part of the monograph of the first author presented at Federal University of Pará, Brazil.

\section{References}

Anderson C.R, Chabaud G.A, Willmott S. 2009. Keys to the Nematode Parasites of Vertebrates, Archival Volume London: Cab International

Barus V., Coy Otero A. 1968. Freitasia teixerai gen. n., sp. n. and other nematodes parasitizing Anolis equestris (Squamata: Iguanidae). Folia Parasitologica, 15, 41-45

Ben Slimane B., Chabaud A.G., Durette-Desset M. 1996. Nematodes Trichostrongylidae parasites of amphibians and reptiles: taxonomic, phylogenetic and biogeographic problems. Systematic Parasitology, 35, 179-206. DOI: 10.1007/BF00009639 (In French)

Ben Slimane B., Durette-Desset M.C. 1993. Four new species of Oswaldocruzia Travassos, 1917 (Nematoda: Trichostrongylidae) parasites of Ecuador Amphibians. Revue Suisse de Zoologie, 100, 113-136. 9 (In French)

Ben Slimane B., Durette-Desset M.C., Chabaud A.G. 1995. Speciation events in Oswaldocruzia (Nematoda: Trichostrongylidae Molineidea) of Guadeloupe Lizards parasites. Parasite, 2, 373-383 (In French)

Campião K.M., Morais D.H., Dias O.T., Aguiar A., Toledo G., Tavares L.E.R., Da Silva R.J. 2014. Checklist of helminth parasites of amphibians from South America. Zootaxa, 3843, 193. DOI: 10.11646/zootaxa.3843.1.1

Dos Santos S.P., Ibáñez R., Ron S.R. 2015. Systematics of the Rhinella margaritifera complex (Anura, Bufonidae) from western Ecuador and Panamá with insights in the biogeography of Rhinella alata. ZooKeys, 501, 109-145. DOI: 10. 3897/zookeys.501.8604

Feitosa L.A., Furtado A.P., dos Santos J.N., Melo F.T. 2015. A new species of Kentropyxia Baker, 1982 parasitic in the small intestine of Osteocephalus taurinus Steindachner (Anura: Hylidae) from the Brazilian eastern Amazon. Systematic Parasitology, 92, 251-259. DOI: 10.1007/s11230-015-9600-1

Frost D.R. 2014. Amphibian Species of the World: An Online Reference, Version 6.0. American Museum of Natural History, USA. Available at http://research.amnh.org/vz/herpetology/amphibia/index.html. Archived by WebCite at http://www.webcitation.org/6RVXmH2Ls on 31 March 2015

Guerrero R. 2013. Two new species of Oswaldocruzia (Nematoda: Trichostrongylina: Molineoidea) parasites of the cane toad Rhinella marina (Amphibia: Anura) from Peru. Acta Parasitologica, 58, 30-36. DOI: 10.2478/s11686-013-0103-4

Lavilla E.O., Caramaschi U., Langone J.A., Pombal Jr. J.P., De Sá R.O. 2013. The identity of Rana margaritifera Laurenti, 1768 (Anura, Bufonidae). Zootaxa, 3646, 251-264. DOI: 10.11646/zootaxa.3646.3.4

Moravec F., Kaiser H. 1995. Helminth parasites from West Indian frogs, with descriptions of two new species. Caribbean Journal of Science, 31, 252-268 
Moravec J., Cusi J.C., Córdova J.H., Gvoždík V. 2014. A new species of the Rhinella margaritifera species group (Anura, Bufonidae) from the montane forest of the Selva Central, Peru. ZooKeys, 371, 35-56. DOI: 10.3897/zookeys.371.6580

Pérez-Vigueras I. 1938. Notes on some new parasitic nematodes of Cuba. Livro Jubilar de Travassos, 501-508 (In Spanish)

Prosser S.W., Velarde-Aguilar M.G., León-Règagnon V., Hebert P.D. 2013. Advancing nematode barcoding: A primer cocktail for the cytochrome coxidase subunit I gene from vertebrate parasitic nematodes. Molecular Ecology Resources, 13, 11081115. DOI: 10.1111/1755-0998.12082

Santos J.N., Giese E.G., Maldonado Jr. A.J., Lanfredi R.M. 2008. A new species of Oswaldocruzia (Molineidae: Nematoda) in Chaunus marinus (Amphibian: Bufonidae) (Linneaus, 1758) from Brazil. Journal of Parasitology, 94, 264-268. DOI: $10.1645 / \mathrm{GE}-1336.1$

Received: March 1, 2016

Revised: March 28, 2016

Accepted for publication: March 31, 2016
Svitin R., Kuzmin Y. 2012. Oswaldocruzia duboisi (Nematoda, Molineidae): morphology, hosts and distribution in Ukraine. Vestnik Zoologii, 46, 195-203. DOI: 10.2478/v10058-012-0017-x

Thompson J.D., Higgins D.G., Gibson T.J. 1994. CLUSTAL W: improving the sensitivity of progressive multiple sequence alignment through sequence weighting, position-specific gap penalties and weight matrix choice. Nucleic Acids Research, 22, 4673-4680. DOI: 10.1093/nar/22.22.4673

Travassos L. 1917. Trichostrongylidas brazileiras (5a Nota previa). Brasil Medico, 31, 1-4

Vicente J.J, Rodrigues H.O, Gomes D.C, Pinto R.M. 1991. Nematodes in Brazil 2nd part: Amphibian Nematodes. Revista Brasileira de Zoologia, 7: 549-626 (In Portuguese) 